\title{
PENGUATAN SIKAP TINDAK WIRAUSAHA MELALUI PENDIDIKAN TEKNOLOGI PENGOLAHAN HASIL PERTANIAN
}

\author{
Asih Kuswardinah \\ Fakultas Teknik Universitas Negeri Semarang \\ asihkuswardinah@yahoo.co.id
}

\begin{abstract}
Abstrak: Menguatkan Sikap Tindak Wirausaha Melalui Pendidikan Teknologi Pengolahan Hasil Pertanian. Tujuan penelitian ini adalah: menemukan model penguatan sikap tindak wirausaha melalui pemberdayaan Kelompok Wanita Tani (KWT). Penelitian ini dilakukan di Kabupaten Semarang, Propinsi Jawa Tengah. Pengambilan sample dilakukan secara purposif sampling, dengan pertimbangan sekelompok subyek yang memiliki karakteristik: sebagai anggota KWT kategori proaktif, reaktif dan nonaktif; memiliki status sosial ekonomi rendah, berdomisili di Kabupaten Semarang. Jumlah sample 198 orang. Penelitian ini adalah penelitian tindakan (Action Research), yang diharapkan menghasilkan model dan modul pemberdayaan KWT. Hasil penelitian menunjukkan bahwa: (1) tingkat pengetahuan siswa paska pendidikan pada kategori baik; (2) terbukti ada peningkatan pengetahuan siswa paska pendidikan. Berdasarkan temuan hasil penelitian, beberapa saran yang dapat disampaikan khususnya untuk dinas terkait di Kabupaten Semarang, yakni: Bagi Dinas Pertanian: akan lebih tepat memasukan program kewirausahaan; pengolahan pangan hasil pertanian (lokal). ke dalam program kerja rutin KWT.
\end{abstract}

Kata kunci: Pendidikan; Wirausaha; Pengolahan hasil pertanian; Sikap.

\section{STRENGTHENING STUDENTS ENTREPRENEURSHIP THROUH EDUCATION OF PROCESSING TECHNOLOGY OF FARMING}

\begin{abstract}
Strengthening Students Entreprenuership Through Farming Process Technology Education. This research was aimed at investigating model of strengthening student entrepreneurship through Female Farmer Group (FFG). This research was conducted in Kabupaten Semarang, the Province of Jawa Tengah. The 198 people was the sample and was selected purposively from the population. Subject was selected based on some criteria: pro-active, reactive, and non-active member of FFG; low economics condition, and Kabupaten Semarang inhibitants. This action research was expected to produce model and module for FFG empowerment. The results of research: (1) student knowledge was good; (2) student achievement was improved. This research recommendation is for the county office of farming, that it is better to provide entrepreneurship program for FFG empowerment.
\end{abstract}

Keyword: education, entrepreneurship, processing technology of farming

\section{PENDAHULUAN}

Penelitian ini bertujuan, menumbuhkan minat wirausaha anggota KWT melalui pendidikan wirausaha dan teknologi pengolahan hasil pertanian, sebagai upaya pengentasan kemiskinan khususnya keluarga wanita tani.

Secara umum tujuan yang ingin dicapai dalam penelitian ini adalah: menemukan model menguatkan sikap tindak wirausaha melalui pemberdayaan KWT. Selanjutnya diharapkan menghasilkan modul wirausaha dan teknologi pengolahan hasil pertanian.

Sebagian besar (> 70\%) anggota KWT di kabupaten Semarang berpendidikan rendah (Observasi 2007). Rendahnya tingkat pendidikan akan membatasi capaian pengetahuan mereka. 
Lebih dari 42,5\% anggota KWT di Kabupaten Semarang berada dalam tingkat sosial ekonomi lemah, (Observasi 2007; 2009). Sebagian besar dari mereka tidak memiliki kegiatan yang dapat menghasilkan. Rasionalnya, sebuah keluarga petani dengan tingkat social ekonomi lemah (miskin), tidak mampu berpikir tentang pendidikan, kesehatan, sandang dan pola menkonsumsi pangan secara baik/sehat. Bagi mereka, rasa kenyang merupakan kondisi yang selalu dicari setiap hari. Mereka tidak pernah berpikir tentang keluarga sejahtera, masa depan; bahkan mereka tidak pernah faham apa yang disebut dengan sejahtera atau masa depan. Kondisi demikian terjadi karena mereka tidak memiliki pengetahuan atau keterampilan yang memadai sebagai bekal memperoleh pekerjaan.

Penyuluhan dari petugas pertanian terhadap anggota KWT masih terbatas pada ketepatan jenis tanaman pangan yang ditanam disesuaikan dengan jenis hamparan tanah setempat; dan cara beternak. Namun bagaimana tindak lanjut hasil pertanian tanaman pangan Berkaitan dengan kondisi tersebut, anggota KWT dalam status ekonomi lemah/ miskin bersifat stagnan, mereka tetap tidak mampu mandiri karena tidak memiliki modal baik pengetahuan, keterampilan maupun materi yang dapat diandalkan untuk ikut berwirausaha dalam upaya meningkatkan tingkat ekonominya (observasi, 2009). Hasil penelitian menemukan: intervensi melalui pendidikan kepemimpinan berpengaruh positif terhadap kinerja pengurus dan anggota KWT dalam melaksanakan programnya (Asih, 2006). Berangkat dari teori Green (perubahan perilaku hidup sehat), Pemberdayaan KWT melalui peningkatan pengetahuan kesehatan ibu \& anak dan pengetahuan makanan berpengaruh positif terhadap tindakan preventif kekurangan kalori dan protein anak (Asih, 2005, 2007).

Berdasarkan hasil-hasil penelitian tersebut, peneliti menganalogikan teori Green dapat dijadikan acuan dalam pemberdayaan KWT melalui pendidikan wirausaha dan teknologi pengolahan hasil pertanian lokal, selanjutnya akan menghasilkan model pemberdayaan KWT yang tepat dalam upaya menumbuhkan minat wirausaha bagi anggota KWT. Bantuan pemerintah bagi masyarakat miskin selama ini masih bersifat langsung habis; misal: bantuan raskin, pemberian SLT.

Penelitian ini akan sangat penting artinya bagi keluarga KWT, dalam upaya meningkatkan social ekonomi keluarga melalui wirausaha pangan pengolahan hasil pertanian. Sedang arti penting lain dalam penelitian ini adalah membantu pemerintah dalam menyusun kebijakan strategi pengentasan kemiskinan melalui pemberdayaan Kelompok Wanita Tani.

Penddidikan dapat diartikan sebagai usaha sadar, sengaja dan bertanggungjawab yang dilakukan pendidik terhadap peserta didik ketaraf yang lebih maju. Pendidikan sebagai sustu produk meliputi semua perubahan yang berlangsung sebagai hasil partisipasi individu dalam pengalaman belajarnya.

Pendidikan diklasifikasikan menjadi 3 golongan (Munib, 2004), yaitu: pendidikan informal, pendidikan formal, pendidikan nonformal. Pelaksanaan pendidikan nonformal yang berupa penyuluhan bagi anggota KWT merupakan salahsatu strategi untuk menumbuhkan motivasi wirausaha bagi peserta didik yang dalam hal ini adalah anggota KWT.

Pendidikan wirausaha dan teknologi pengolahan hasil pertanian dalam penelitian ini 
adalah satu bentuk pemberdayaan KWT, merupakan kegiatan pemberian pengetahuan pada anggota KWT agar mereka mampu mendapatkan hasilnya. Berdasarkan observasi (Asih, 2007), KWT di kabupaten Semarang khususnya para pengurus pada dasarnya memiliki kemauan yang tinggi untuk berwirausaha sesuai dengan sumberdaya lokal. Untuk mengawalinya diadakan penyuluhan dari penyuluh pertanian lapangan (PPL), materi yang diberikan hanya terbatas pada tanaman yang dikembangkan sesuai dengan kondisi hamparan tanah setempat dan juga tentang bagaimana mengolah hasilnya, namun tidak ada tindak lanjutnya sehingga kurang efektif. Disamping itu, kurang dapat dimengerti anggota KWT, mengingat tingkat pendidikan mereka yang sangat terbatas.

\section{Wirausaha}

Istilah wirausaha sering dipakai dengan istilah wiraswasta. Wiraswasta berasal dari bahasa sansekerta yang terdiri atas tiga kata yaitu: wira, swa,dan sta. Wira adalah manusia unggul, teladan, berjiwa besar, berani; swa artinya sendiri dan sta artinya berdiri. Bertolak dari ungkapan etimologis tersebut maka wiraswasta berarti keberanian dalam memenuhi kebutuhan serta memecahkan permasalahan hidup dengan kekuatan yang ada pada diri sendiri (Wasty dalam Buchari Alma, 2001).

Wirausaha merupakan proses dinamik untuk menciptakan tambahan kemakmuran. Tambahan kemakmuran ini diciptakan oleh individu wirausaha yang mengandung resiko, menghabiskan waktu dan menyediakan berbagai produk barang atau jasa. Pengertian wirausaha tersebut akan tersimpul konsep-konsep baru seperti: situasi baru, mengorganisisr, menciptakan, kemakmuran dan menanggung resiko. Wirausaha dijumpai pada semua profesi, khusus dalam penelitian ini adalah yang berkaitan dengan pangan baik produk maupun jasa.

Ada 3 tipe utama wirausaha, yakni: (1) Wirausaha Ahli, yaitu seorang penemu yang cenderung bergerak dalam bidang penelitian membuat model; (2) The Promoter adalah inidividu yang tadinya mempunyai latar belakang pekerjaan sebagai sales atau bidang lain, kemuadian mengembangkan usaha sendiri berdasarkan keterampilan yang ia miliki.; (3) General manager, adalah seorang individu yang ideal yang secara sukses bekerja pada sebuah perusahaan.

Ada berbagai macam profil Wirausaha menurut Zimmerer \& Scarborough yang berkembang di masyarakat, antara lain adalah: Women Entrepreneur; Minority Entrepreneur; Imigrant Entrepreneur; Part Time Entrepreneur; Home-Based Entrepreneur.

Wanita wirausaha. Dorongan dari R.A Kartini yang sampai sekarang dikenal dengan emansipasi wanita. Emansipasi wanita menjadikan peluang bagi wanita untuk berkarya sederajat dengan pria.

Faktor-faktor yang menunjang wanita wirausaha antara lain: (1) Naluri kewanitaan yang bekerja lebih cermat, menjaga keharmonisan, kerjasama dalam rumahtangga dapat diterapkan; pandai mengantisipasi masa depan. (2) Lingkungan kebutuhan hidup, seperti: menjahit, membordir pakaian, membuat kue, aneka masakan, kosmetik dan sebagainya. (3) Majunya dunia pendidikan wanita sangat mendorong perkembangan wanita karir. 
Faktor-faktor yang menghambat wanita wirausaha antara lain: (1) Faktor kewanitaan; (2) Faktor sosial, ekonomi, dan budaya. Wanita bertanggungjawab pada urusan rumahtangga; (3) Faktor emosional lebih dominan dimiliki wanita. (4) Faktor ekonomi, sifat wanita, jika memasang harga jual terlalu tinggi, jika membeli menawarnya terlalu rendah.

Sifat yang harus dimiliki oleh seorang wirausaha menurut BN. Marbun, 1993: percaya diri; berorientasi tugas dan hasil; pengembil risiko; kepemimpinan; keorisinilan; berorientasi kemasa depan.

\section{Teknologi Pengolahan Hasil Pertanian}

Hasil pertanian di Kabupaten Semarang yang sebagian besar ditangani KWT antara lain: buah-buahan, kacang-kacangan, sumber hidrat arang, ikan, telur, palawija. Berkaitan dengan pengolahan hasil pertanian, salah satu hal yang perlu dipelajari antara lain tentang pengawetan.

Secara garis besar, pengawetan dibagi menjadi 3 golongan, yaitu: (1) Pengawetan secara alami, proses pengawetan alami meliputi pemanasan dan pendinginan; (2) Pengawetan secara biologis, proses pengawetan yang dilakukan melalui fermentasi atau peragian. (3) Pengawetan secara kimia, proses pengawetan menggunakan bahan-bahan kimia, seperti: gula pasir, garam dapur, natrium benzoat.

Proses pengasapan juga termasuk cara kimia, sebab bahan-bahan kimia dalam asap dimasukan ke dalam bahan makanan yang diawetkan. Jika jumlah pemakaian bahan pengawetnya tepat, pengawetan bahan kimia dalam makanan sangat praktis karena dapat menghambat berkembangbiaknya mikroorganisme, seperti jamur atau kapang, bakteri dan ragi. beberapa pengawetan cara kimia praktis digunakan untuk produk hasil: buah-buahan, kacang-kacangan, macam-macam ubi, macam-macam ikan.

Berkaitan dengan pengolahan hasil pertanian lokal di kelompok Wanita Tani Kabupaten Semarang, ketiga jenis pengawetan tersebut dapat diterapkan. Prodak wirausaha pangan pengolahan hasil pertanian yang sudah ada di KWT adalah: ikan, kripik tempe, krupuk dele, maca-macam criping ubi, jahe instan, telur asin, gula aren.

\section{Sikap}

Sikap adalah suatu respon evaluatif. Respon akan timbul jika individu dihadapkan pada suatu stimulus yang menghendaki adanya reaksi individual. Respon evaluatif merupakan bentuk evaluasi yang dinyatakan sebagai sikap itu timbulnya didasari oleh proses evaluasi dalam diri individu yang memberi kesimpulan terhadap stimulus dalam bentuk nilai baik-buruk, positifnegatif, menyenangkan- tidak menyenangkan, yang kemudian mengkristal sebagai potensi reaksi terhadap objek sikap.

Sebagian dari hasil-hasil penelitian memperlihatkan adanya indikasi yang kuat antara sikap dan perilaku; namun temuantemuan penelitian mengenai huibungan antara sikap dengan perilaku memang belum konklusif. Dalam penelitian ini pendidikan wirausaha dan teknologi pengolahan hasil pertanian akan meningkatkan pengetahuan dan dihapkan akan menguatkan sikap tindak wirausaha anggota KWT. Pengetahuan, keyakinan dan sikap merupakan predisposisi perilaku.

\section{Kelompok Wanita Tani (KWT)}

Kelompok Wanita Tani (KWT) adalah sebuah organisasi wanita tani, merupakan 
wadah berkumpulnya para wanita tani yang memungkinkan para anggotanya saling memberi dan menerima informasi. KWT diharapkan memiliki peran dalam meningkatkan kesejahteraan keluarga khususnya meningkatkan status sosial dan ekonomi bagi para anggotanya.

Secara umum tujuan yang ingin dicapai dalam penelitian ini adalah: menemukan model peningkatan pengetahuan wirausaha dan teknologi pengolahan hasil pertanian melalui pemberdayaan KWT (dalam bentuk pendidikan). Adapun secara khusus tujuan dalam penelitian ini adalah:

1. Mendeskripsikan tingkat pengetahuan wirausaha anggota KWT;

2. Mendeskripsikan tingkat pengetahuan teknologi pengolahan hasil pertanian (local) anggota KWT;

3. Mendeskripsikan tingkat kekuatan sikap tindak wirausaha anggota KWT;

4. Menemukan model menguatkan sikap tindak wirausaha sebagai upaya peningkatan pendapatan keluarga khususnya bagi keluarga KWT.

Bidang pengembangan Teoritis; Hasil penelitian ini secara umum menjelaskan dasardasar teoritis tentang pengembangan peran pendidikan melalui pemberdayaan KWT kaitannya dengan usaha meningkatkan derajat perekonomian keluarga khususnya dari anggota KWT melalui kemampuan akademiknya sendiri; Sedangkan secara khusus, temuan penelitian ini membangun konsep teori untuk menjawab pertanyaan bagaimana melakukan tindakan pengentasan kemiskinan melalui jalur pendidikan bekerjasama dengan KWT.

Bidang Pemanfaatan Praktis; Temuan Penelitian ini diharapkan dapat diaplikasikan sebagai salah satu konsep pendidikan dalam pengembangan fungsinya melalui pemberdayaan KWT

\section{METODE PENELITIAN}

Menurut jenisnya, penelitian ini termasuk penelitian terapan; Menurut metodenya, penelitian ini termasuk penelitian tindakan (Action Research), sedangkan menurut tingkat eksplanasinya, penelitian ini termasuk penelitian deskriptif karena hanya untuk mengetahui nilai variabel mandiri kekuatan sikap tindak anggota KWT.

Penelitian ini dilakukan di Kabupaten Semarang. Berdasarkan dokumentasi Dinas Pertanian Kabupaten Semarang (2009) jumlah KWT aktif terdaftar 34.

Populasi penelitian ini ialah seluruh anggota dalam KWT yang berdomisili di Kabupaten Semarang. Berdasarkan dokumentasi (2009) Dinas Pertanian Kabupaten Semarang tercatat 34 KWT, jumlah keseluruhan anggota KWT aktif 440. Pengambilan sampel mengacu pada Sugiyono, berdasarkan perhitungan dengan taraf kesahihan 5\% ditetapkan sebanyak 195 dari populasi 440. ; Hasil FGD, ditetapkan jumlah anggota sebagai sampel yang memenuhi kriteria sebesar 198. Variabel penelitian ialah: kekuatan sikap tindak wirausaha anggota KWT. (variabel mandiri)

Teknik analisis data digunakan untuk menganalisis: deskripsi persentase: tingkat pengetahuan ( kewirausahaan, pengolahan hasil pertanian) dan kekuatan sikap wirausaha anggota KWT.

Model Kerangka Analisis Penelitian, disajikan pada gambar 1 berikut: 


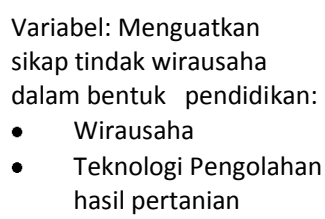
hasil pertanian

Identifikasi Tingkat

Pengetahuan, Anggota KWT, yang meliputi:

- Wirausaha

- Teknologi Pengolahan hasil pertanian
Kekuatan sikap tindak wirausaha anggota KWT.

Gambar 1. Model Kerangkan Analisis Penelitian

\section{HASIL PENELITIAN}

Kabupaten Semarang merupakan salah satu Kabupaten di Propinsi Jawa Tengah Batas administrasi Kabupaten Semarang adalah: sebelah utara berbatasan dengan Kota Semarang dan Kabupaten Demak. Sebelah selatan berbatasan dengan Kabupaten Boyolali dan Kabupaten Magelang. Sebelah timur berbatasan dengan Kabupaten Boyolali dan Kabupaten Grobogan. Sebelah barat berbatasan dengan Kabupaten Temanggung dan Kabupaten Kendal. Ditengah-tengah wilayah ini terdapat Kota Salatiga. Sampai saat ini, sektor pertanian di Kabupaten Semarang masih merupakan sektor pertanian yang menunjang perekonomian. $73,88 \%$ digunakan untuk usaha pertanian.

\section{Pemberdayaan KWT}

Pelaksanaan Pemberdayaan KWT dalam bentuk pendidikan, diawali dari diagnosis awal melalui dokumen KWT kabupaten Semarang (2009), mendeskripsikan bahwa: tingkat pendidikan anggota KWT $70 \%$ rendah; tingkat sosial ekonomi anggota KWT 42,5\% rendah; baru $20 \%$ dari jumlah KWT yang melakukan wirausaha namun masih banyak kendala; dalam manajemen SDM, 50\% dari seluruh KWT di kabupaten Semarang berada pada kategori KWT non aktif. Keberadaan KWT di kabupaten Semarang saat ini berjumlah 34 (dokumen,

2009). Deskripsi Hasil Penelitian Pemberdayaan KWT (dalam bentuk pendidikan):

Tabel 1 dan 2 berikut ini adalah deskripsi hasil penelitian, tingkat pengetahuan wirausaha dan teknologi hasil pertanian anggota KWT di kabupaten Semarang:

Tabel 1. Dskripsi Tingkat Pengetahuan Wirausaha Anggota KWT

\begin{tabular}{|l|l|c|l|l|}
\hline \multicolumn{1}{|c|}{ Kategori } & \multicolumn{1}{c|}{$\mathbf{\%}$} & $\mathbf{\%}$ & Batas & \multicolumn{1}{|c|}{ Ket } \\
\hline Sangat Tinggi & 81 & 40,9 & 25 & $\begin{array}{l}\text { Mean } \\
=19,7\end{array}$ \\
\hline Tinggi & 85 & 42,9 & 21 & $\begin{array}{l}\text { Kategori } \\
=\text { Tinggi }\end{array}$ \\
\hline Sedang & 31 & 15,7 & 17 & $(>17)$ \\
\hline Rendah & 1 & 0,5 & 13 & \\
\hline Sangat Rendah & 0 & 0,0 & 9 & \\
\hline & 198 & $100 \%$ & & \\
\hline
\end{tabular}

Tabel 1 di atas menunjukkan bahwa tingkat pengetahuan wirausaha anggota KWT termasuk dalam kategori tinggi ( Mean > Batas sedang).

Tabel 2: Dskripsi Tingkat Pengetahuan Teknologi Pengolahan Hasil Pertanian Anggota KWT.

\begin{tabular}{|l|c|c|l|l|}
\hline \multicolumn{1}{|c|}{ Kategori } & f & \% & Batas & Ket \\
\hline Sangat Tinggi & 55 & 27,8 & 30 & $\begin{array}{l}\text { Mean } \\
=23,8\end{array}$ \\
\hline Tinggi & 122 & 61,6 & 25,2 & $\begin{array}{l}\text { Kategori } \\
=\text { Tinggi }\end{array}$ \\
\hline Sedang & 20 & 10,1 & 20,4 & $(>20,4)$ \\
\hline Rendah & 1 & 0,5 & 15,6 & \\
\hline $\begin{array}{l}\text { Sangat } \\
\text { Rendah }\end{array}$ & 0 & 0,0 & 10,8 & \\
\hline & 198 & $100 \%$ & & \\
\hline
\end{tabular}

Tabel 2 diatas menunjukkan bahwa tingkat pengetahuan teknologi pengolahan hasil pertanian anggota KWT termasuk dalam kategori tinggi ( Mean > Batas sedang ).

Tabel 3: Dskripsi Kekuatan Sikap Anggota Terhadap Wirausaha

\begin{tabular}{|l|c|c|l|l|}
\hline \multicolumn{1}{|c|}{ Kategori } & f & \multicolumn{1}{c|}{$\%$} & Batas & \multicolumn{1}{|c|}{ Ket } \\
\hline Sangat Kuat & 102 & 51,5 & 25 & $\begin{array}{l}\text { Mean } \\
=20,7\end{array}$ \\
\hline Kuat & 86 & 43,4 & 21 & $\begin{array}{l}\text { Kategori } \\
=\text { Kuat }\end{array}$ \\
\hline Sedang & 8 & 4,0 & 17 & $(>17)$ \\
\hline Lemah & 2 & 1,0 & 13 & \\
\hline $\begin{array}{l}\text { Sangat } \\
\text { Lemah }\end{array}$ & 0 & 0,0 & 9 & \\
\hline & 198 & $100 \%$ & & \\
\hline
\end{tabular}


Tabel 3 di atas menunjukkan bahwa tingkat kekuatan sikap anggota KWT terhadap wirausaha termasuk kategori kuat ( Mean > Batas sedang). Berdasarkan temuan hasil penelitian, gambar 1 berikut ini adalah Model menguatkan sikap tindak wirausaha bagi anggota KWT.

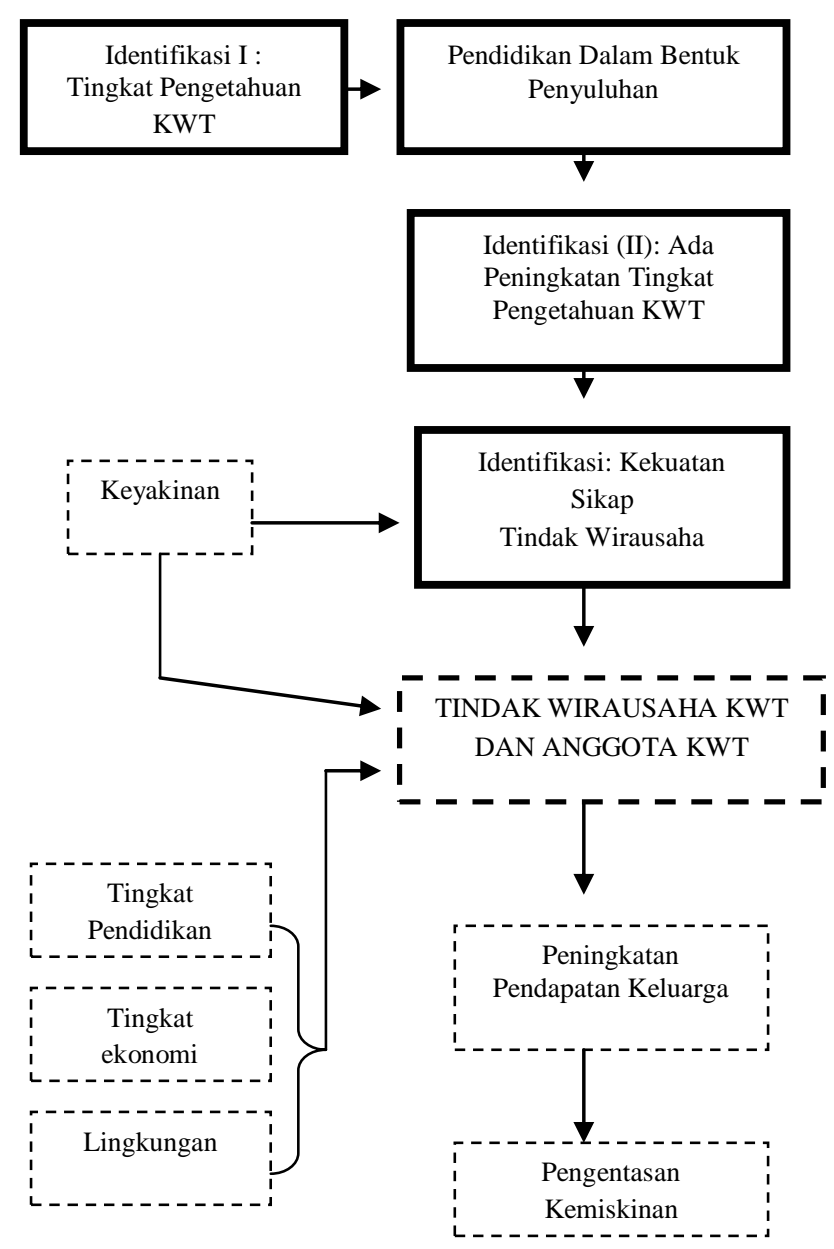

Keterangan:

$$
\begin{array}{ll}
------------- & =\text { Belum Dianalisis } \\
& =\text { Dianalisis }
\end{array}
$$

Gambar 2. Model Menguatkan Sikap Tindak Wirausaha Anggota KWT

\section{KESIMPULAN}

Tingkat pengetahuan, paska intervensi melalui pendidikan wirausaha dan teknik pengolahan hasil pertanian termasuk pada kategori baik. Hasil analisis deskripsi tersebut jelas menunjukkan adanya peningkatan pengetahuan yang sebelum intervensi melalui pendidikan wirausaha pangan pengolahan hasil pertanian berada pada kategori sedang;

Berdasarkan temuan hasil penelitian ini ada beberapa saran yang dapat disampaikan khususnya untuk dinas terkait di Kabupaten Semarang, yakni:

- Bagi Dinas Pertanian: akan lebih baik memasukan program kewirausahaan; pengolahan pangan hasil pertanian (lokal); manajemen SDM ke dalam program kerja rutin KWT .

- Bagi anggota KWT: akan lebih baik jika terus berlatih mengolah hasil pertanian lokal dengan berbagaim vasiasi untuk meningkatkan nilai jual.

\section{DAFTAR PUSTAKA}

Abrams and Brown, (1990). Self Conciousness and Social Identity, Self regulation as a Group member.

Anonim, (1980). Kapita Selekta Pengembangan dan Pembinaan Kelompok Tani dalam Intensifikasi Tanaman Pangan. Jakarta: Deptan.

Bernard M Bass, (1991). Leadership Pschology ang Organizational Behaviour. New York: Harper and Row.

Briance Mascarenhas, (1990). Strategic Group Dinamic. Academy of Management, Journal, June.

Buchari Alma, (2001). Kewirausahaan. Bandung: Penerbit Alfabeta.

Gibson, Ivancecevich, Donnelly, (1995). Organization. Published by arrangement with Ricard D. Irwin, Inc.

Green, L. W., et al. (1992). Helath education planning a diagnostic approach. Boston: Mayfield Publishing Company, John Hopkins University.

Manulang. (1990). Management Personalia. Jakarta: Penerbit Ghalia Indonesia.

Purnawan Junadi, (1995). Pengantar Analisis Data. Jakarta: Penerbit PT Rineka Cipta

Saifuddin Azwar, (1986). Reliabilitas dan Validitas. Yogyakarta: Penerbit Liberti. 
Saifuddin Azwar, (1997). Metode Penelitian. Yogyakarta: Penerbit Pustaka Pelajar.

Sikap Manusia Teori dan pengukurannya.
Sugiyono, (2003). Metode Penelitian Administrasi. Bandung: Penerbit CV Alfabeta

Widodo JP, (1993). Metode Penelitian dan Statistik Terapan. Surabaya: Airlangga University 